以上の結果を総括すると次のようになる。

1）電子線前照射した木綿は，水を加点ないスチレン ・メタノール柔でるすみやかに重合し, その重合速度は 含水スチレン・メタノール系での結果よりむしろ大であ D大。

2）アルコール類を中心にして, 種々の溶剤を用いて グラフト重合を就こなうと，メダノール，エタノール， プロパノールまではグラフト重合は相当さかんにおこす が，それ以上の高級アルコールではグラフト重合は抗こ り以くい。しか，アミルアルコールのようにグラフト 重合が注とんどおこらない場合にも承を添加するとダ フト重合がおこつた。ベンゼン，アセトンを用いて重合 してあはとんどグラフトは扎こらなからた。

3）電子線前照射を種々の媒体中でおこなつて质たが 空気中での結果と大差はなかつた。

4） $r$ 線を用いて実験した場合は，重合速度は，真空 中前照射後空気にふれることなく電合した場合，空気中 前照射後真空中で重合した場合，真空中で前照封後一度 空気にさらした後重合した場合の順に小さくなり，去の 比は 8:4:3であつた。また種々の媒体中で $\gamma$ 線照射 した場合には，真空中，笁気中どちらの照射でむベンゼ
ン中ではいちじるしくグラフト活性が低下した。

5）電子線前照射後，空気中または水中で加熱処理す ると，グラフト活性は温度が高いはど，また時間が長い

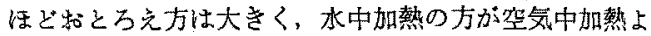
りもはるか速やかに活性点は失われる。

6) アクリル酸む木綿にグラフトすることがわかつ た。?:

付記：本研究は日本綿業研究所よりの委託研究として 行なわれた8ので，高分子学会第 9 回年次大会 (昭和 35 年 5 月 28 日）で報告し，日本放射線高分子研究協会年 報，1，64（1958～1959）に大要を揭載した。

文䓟

1) 桜田，周田，木村；䋐学誌，18，687 (1962)

2) D. Ballantine, A. Glines, G. Adler, D. J. Metz ; J. polymer Sci., 34, 419 (1959)

3) 桜田, 岡田, 木村, 嶺川; 高分子学会第 10 会年 次大会（昭和 36 年 5 月 27 日）

4) 桜田, 岡田, 木村, 香山；第 4 回日本アイントー ブ会諩（昭和 36 年 10 月 12 日）

5）岩琦，宮本；工化，41 B，222（1938）

6) 大西；私信

\title{
第了報 前照射法による染色綿布へのグラフト重合
}

\section{1. 緒言}

第 1 報1)では，電子線前照射した木綿のダラフト重合 以扣よぼす前照射線量, 線量率, 重合温度, 重合時間の 影響を，第 2 報2)では重合液の溶凧，照射条件の影響， 照射媵重合までの処理によるグラフト活性の安定性など そついて報告した。

本報では，綿菜研究所よりの委託研究の一環しして， 染色された綿布への前照射法によるグラフト重合反心を 行なつた。木綿へのグラフト重合反応を，現在の綿布の 樹脂加工々同様の方法で実施するとすれば，染色された 䄸布の色が放射線でどの程度退色するか，綿布に染着し た染料ならびに残存した染色の助剤がグラフト重合にい がる影響を与省るか，染料が重合反応中化学变化を受 け，出るいは溶解して脱離することが市いかどうか，と いつたようなことが問題になるのでこの点について研 究した。

\section{2. 実験}

\section{1 試 料}

この寒駼に用いた染色綿布は，第 1，2 報で用いたと 同じ綿布を，京都工芸䋐維大学田中隆吉教授のところて
染めていただいたものである。 スチレン，メタノール，水の精製などは第 1 報にの心゙ たと和りである。

\section{2 強伸度}

強伸度はインストロン試験機を用い $22^{\circ} \mathrm{C}, 65 \% \mathrm{RH}$, 引張速度 $1 \mathrm{~cm} / \mathrm{min}$ で測定した。測定には $3 \times 0.5 \mathrm{~cm}^{2}$ の大きさの綿布を用い,タテ方向の強伸度をしらべた。 強度はウ $1 \mathrm{~cm}$ 安たりの值で示した。

\section{3 照射および重合方法}

照射扰よび重合方洗は第1 報でのべたと全く同じであ る。

\section{3. 実験結果および考察}

綿布に染色された色の放射線に対する堅る万度につい ては，田中，瀨古゙により他の場所で詳細に報告がある はずであるが，電子線の $10 \mathrm{Mrad}$ 程度の照射に対して はいずれるかなり安定である。この結果を少し詳しくの べると，電子線照射により，Nippon Sky Blue 390 Thioflavine $T$, Indigo, Procion Brilliant Red H 3 BS で染色した綿柏は明度を增加し，建染染料，Sirius Supra Blue $6 \mathrm{G}$, Magenta large Crystal, Methyl Violet, Sulphur Brown, Naphthol AS+Fast Scarlet G Base, 
Alcian Blue 8GN などで染色したものは注とんど明度 が変化せず，これら以外の染料で染め大綿布は明度が減 少することが諗められた。また電子線で照射すると染色 布の色調がくす，光により処理すると退色して淡くな るが，電子線姑よび光に対する堅ろ5度を比較してみる と，建染染料，反応性染料の上5な耐光堅万5度の高い すのは電子線に対してもすぐれた堅ら5度を示し，塩基 性染料㤔光堅万弓度が低いにもかかわらず電子線によ く酎えることがかかつた。

これら染色布の電子線照射に上る強度の変化を Table 1 K, 伸度の変化を Table 2 飞示す。末染色布, 染色 布の強伸度恃電子線の照射により低下する。未染色布， 染色布の強伸度の低下帮は大体同じ程度で努り，色の堅 ろろ度や後にのベるグラフト重合で認められたような染

Table I Change of Tensille Strength $(\mathrm{g} / \mathrm{cm})$ of Dyed Cotton by Irradiation with Electron Beams.

\begin{tabular}{|c|c|c|c|c|c|}
\hline \multirow{2}{*}{ Dye } & \multicolumn{5}{|c|}{ Dose, Mrad } \\
\hline & 0 & 1 & 5 & 10 & 20 \\
\hline Undyed cotton & 9.0 & 8.8 & 7.2 & 5.5 & 3.8 \\
\hline Nippon Sky Blue & 8.8 & 8.5 & 6.7 & 5.5 & 3.5 \\
\hline $\begin{array}{c}\text { Magenta large } \\
\text { cryst }\end{array}$ & 9.0 & 8.5 & 7.2 & 5.2 & 3.9 \\
\hline $\begin{array}{l}\text { Naphthol AS } \\
\quad+\text { Scarlet G }\end{array}$ & 8.5 & 7.3 & 5.5 & 4.7 & 3.2 \\
\hline Indanthrene Grey $\mathbf{K}$ & 8.6 & 7.6 & 6.7 & 5.2 & 3.3 \\
\hline $\begin{array}{c}\text { Procion Yellow } \\
\text { HAS }\end{array}$ & 9.1 & 9.0 & 7.4 & 5.7 & 3. 6 \\
\hline Alcian Blue $8 \mathrm{GN}$ & 10.0 & 8.8 & 6.8 & 5.6 & 3.3 \\
\hline Thiogene Orange $R$ & 8.4 & 8.3 & 6.5 & 5.3 & 3.3 \\
\hline
\end{tabular}

Table II Change of Elongation at Break (\%) of Dyed Cotton by Irradiation with Electron Beams.

\begin{tabular}{l|r|r|r|r|r}
\hline \multirow{2}{*}{ Dye } & \multicolumn{5}{|c}{ Dose, Mrad } \\
\cline { 2 - 6 } & 0 & 1 & 5 & 10 & 20 \\
\hline $\begin{array}{l}\text { Undyed cotton } \\
\text { Nippon Sky Blue } \\
\text { 390\% }\end{array}$ & 9.2 & 8.5 & 7.8 & 6.6 & 6.0 \\
$\begin{array}{c}\text { Magenta large } \\
\text { cryst }\end{array}$ & 9.1 & 8.5 & 8.6 & 6.4 & 4.8 \\
$\begin{array}{c}\text { Naphthol AS } \\
\text { +Scarlet G }\end{array}$ & 13.5 & 11.4 & 12.6 & 9.4 & 8.8 \\
$\begin{array}{c}\text { Indanthrene Grey K } \\
\text { Procion Yellow }\end{array} \quad 9.4$ & 8.4 & 8.1 & 7.0 & 5.3 \\
$\quad$ HAS & 9.1 & 9.6 & 8.2 & 7.2 & 6.2 \\
Alcian Blue 8GN & 9.0 & 8.7 & 7.2 & 6.3 & 4.6 \\
Thiogene Orange R & 9.2 & 8.9 & 7.5 & 6.8 & 5.4 \\
\hline
\end{tabular}

Table IIf Grafting of Styrene onto Dyed Cotton in Vacuo at $50^{\circ} \mathrm{C}$.

(1) Composition of monomer solution,

Styrene : Methanol : Water $=30: 70: 5$ by volume

Grafting time, 24 hrs

\begin{tabular}{|c|c|c|c|}
\hline & \multicolumn{2}{|c|}{$\begin{array}{c}\text { Styrene grafted, } \\
\% \\
\text { Dose, Mrad }\end{array}$} & \multirow{2}{*}{$\begin{array}{l}\text { Fading } \\
\text { during } \\
\text { grafting }\end{array}$} \\
\hline & 0 & 14 & \\
\hline Undyed cotton & 1.9 & 620.7 & \\
\hline Naphthol AS+Scarlet G & 0.4 & 168.8 & + \\
\hline Indanthrene Grey $\mathrm{K}$ & 1.8 & 2.3 & + \\
\hline Procion Yellow HAS & 0 & 337.5 & \\
\hline Alcian Blue $8 \mathrm{GN}$ & 0 & 516.6 & \\
\hline Nippon Sky Blue $390 \%$ & 2.5 & 221.5 & \\
\hline Magenta large cryst & 1. 0 & 21.5 & + \\
\hline Thiogene Orange $R$ & 2.7 & 56.2 & \\
\hline
\end{tabular}

(2) Composition of monomer solution, Styrene: Methanol $=30: 70$ by volume Dose, 5 Mrad Grafting time, $24 \mathrm{hrs}$

\begin{tabular}{c|r|c}
\hline Dye & $\begin{array}{r}\text { Styrene } \\
\text { grafted, } \%\end{array}$ & $\begin{array}{c}\text { Fading } \\
\text { during } \\
\text { grafting }\end{array}$ \\
\hline Undyed cotton & 386.5 & \\
Naphthol AS+Scarlet G & 133.4 & + \\
$"$ " +Red RL & 33.5 & + \\
" $\quad$ + Blue B & 38.5 & + \\
" +Garnet GBC & 104.2 & +
\end{tabular}

Procion Blue 3 GS cold bath

17.1

Procion Brill Red H 3 BS

7.7

Mikethrene Blue RSN

Indanthrene Brown $\mathrm{G}$.

Methyl Violet

Thioflavine $T$

16.7

4.5

Sirius Supra Green RR
Indigo

Sirius Blue $6 \mathrm{G} \mathrm{h} / \mathrm{s}$

Nippon Orange GG Conc

Sirius Supra Yellow RT e/c

Sirius Supra Yellow FRAL

Katigen Blue R

Sulphur Brown MC

6.4

8. 6

70.8

11.7

138.2

11. 6

5.3

4.5

Procion blue HBS

Indanthrene Grey $\mathrm{K}$

Procion Yellow HAS

214.5

74. 2

1.3

93.5

Alcian Blue $8 \mathrm{GN}$

304.7

51.1

$$
\text { " Orange F } 3 \mathrm{G}
$$

101. 2

Nippon Sky Blue 390

93.4

Magenta large cryst

5. 3

13. 2

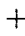

$+$

$+$

$+$

$+$

$+$

Thiogene Orange $\mathrm{R}$ 
料の種類による差は讃められなかつた。

次に，染色綿布を電子線前照射し，これにスキレンを グラフト重合した結果 Table 3 に示す。 Table 3, (1) には $14 \mathrm{Mrad}$ 照射して含水スチレン・かタクール系で 重台した結果を，Table 3,(2) Kは照射量を 5 Mrad K してステレン・メタノール系で重合した結果を示した。 Table 3 の結果る好ると，染色の效果は著しく、いずれ む白試験に比べてグラフト率は低下している。グラフト 重合中脱色も起こらず，しがも゙ラフト率が高度に達す るるのとしては, Sirius Supra Yellow FRAL, Thioflavine $\mathrm{T}$, Alcian Blue $8 \mathrm{GN}$, Sirius Supra Orange F 3G などをあげることができる。これらのるのは 100 \%以上グラフトしているにかかわらず，原布の色調之 ほとんど変わら京い色調老示す。グラフト重合中重合液 中に染料がとけて出たが、Naphthol AS+Scarlet G, Naphthol AS+Garnet GBC で染色した抟はよくスチレ ンをグラフトした。またグラフト重合中重合液中に染料 がとけ出さなからたが，グラフト物が退色したというよ らな例は認められなかつた。 Indanthrene Brown G, Indanthrene Grey K, Sulphur Brown MC などで染色 した布は死とんどグラフトしなかつた。これはこれらの 染料がグラフト重合鎖の生長に刘して強い停止作用をる つているためではないかと思われる。

以上の実験結果は，啇当な染料を選択すれば，染色さ
れな綿布の放射線グラフト重合も充分可能なことを示す すのと思われる。

\section{4. 総括}

染色綿布を電子線前照射し，スチレン・メタノール系 または含水スチレン・メタクール系で真空中, $50^{\circ} \mathrm{C} て$ ダラフト重合するといずれる未染色綿布よりはグラフト 染は低下するが, Sirius SupraYellow FRAL, Alcian

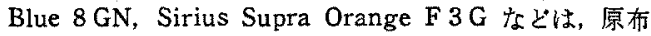
の色調をほとんと失うことなくよくグラフト重合するこ とがかかった。 Indanthrene Brown G, Indanthrene Grey K, Sulphur Brown MCなどで染色した朴はほと んどグラフトしなかつだ。

以上の結果から，適当な染料で染色された線布の放射 線グラフト重合は可能であることがわかつた。

付記：本研究は日本綿業研究所よりの委託研究として 行なわれたるのた，第 3 回放射線化学討論会（昭和 35 年 10 月 14 日) で報告し，日本放射線高分子研究協会 年報，1，65（1958～1959）に大要索揭載した。

\section{文献}

1) 桜田，岡田，木村；瀻学誌，18，687 (1962)

2）桜田，岡田，木村；䋐学誌，18，693 (1962)

3) 田中，瀬古；私信 
compared to that in a monomer solution which contained water. Besides methanol, ethanol and propanol were effective for the grafting whereas butanol and amyl alcohol were not effective. Cotton irradiated in various solvents showed practically the same rate of grafting. The active center for grafting decayed more or less rapidly by heating in air or water.

When irradiation was carried out with Cobalt-60 $\gamma$-rays, the rate of the grafting onto cotton irradiated in vacuo was twice as that irradiated in air, and it was deterred in the case of irradiation in benzene.

Acrylic acid grafted readily onto cotton although a considerable amount of homopolymer was produced.

(Received November 24, 1961)

\section{(III) GRAFT POLYMERIZATION ONTO DYED COTTON FABRIC WITH PRE-IRRADIATION TECHNIQUE}

By Ichirō Sakurada and Fujiko Kimura

(Ösaka Laboratories Japanese Association for Radiation Research on Polymers,

Mii, Neyagawa City, Ōsaka, Japan)

Dyed cotton fabric was preirradiated with eletron beams and then subjected to graft polymerization in vacuo at $50^{\circ} \mathrm{C}$ with a grafting mixture of styrene-methanol or styrene-methanol-water. Although the degree of grafting of dyed cotton fabric was lower than that of undyed one, fabric dyed with Sirius Supra Yellow FRAL, Alcian Blue $8 \mathrm{GN}$ and Sirius Supra Orange F 3 G were grafted with styrene smoothly without much fading. Almost no grafting was observed when fabrics were dyed with Indanthrene Brown G, Indanthrene Grey K or Sulphur Brown MC.

(Received December 13, 1961)

\section{第1 報＼cjkstart電子線前照射による木綿へのスチレンのクラフト重合}

\section{1. 楮言}

ポリエチレン, ポりプロビレン, ポリビニルアルコー ルなどの合成高分子に種々のビニルモノマーを放射線前 㷛射法によつてグラフト重合する研究はナでに，三あ る ${ }^{1,2,3)}$ 。特代ポリビニルアルコールKついては桜田，岡 田，久語 ${ }^{4,5,6)}$ の詳細な報告がある。同じ親水性の高分子 であるたルロースのよ5な天然高分子にビニルモノマー をダラフトすることは，セルロースの性䝷をが品筫を 向上させる目的の上からる興昧ちる問題と思われる。ス チレンをセルロースにグラフトすると，汭ススレンは 安定な䀳水性の化合物でありまたガラス転移点が $80^{\circ} \mathrm{C}$ 付近であるから，グラフト共重合物に熱可塑性をあたえ るのに適当ではないかと考党られる。ぬたアクリロニト リル，アタリルアミド，その他の水溶性のビ二ルモ，マ 一性放射線定用いる以外の方法に上つても七ルロ一ス蟣 維に容易にグラフト重合できるが7,8), スチレンのグラフ 卜重合は他の方法で成功した結果が報告されていない点 からも眮味をもち，故射線を用いて木綿にステレンをグ ラフト重合する研究索㓤こなつた。スチレンのセル口ー スへのケ線前照射法によるグラフト重合については桜

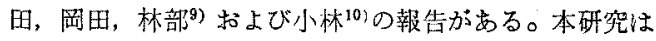
電子線前照射法により試料としては主として編布を用い て実験したが，その主な理由は寒駼上の便宣であり，ま
た工業的には綿布の樹脂加工の延長と考劣られると思 つたからである。しかし綿㵶維にグラフト重合を行ない, 新しい絨維を創造するとい5点にも大さい意味が考えら れる。綿について行なわれた研究は同じセルロース績維 であるスフのグラフト重合に対しても直接参考になると 思われる。

\section{2. 実験}

\section{1 試 料}

東洋紡精練漂白金巾をソックスレー抽出器で 2 日間丈

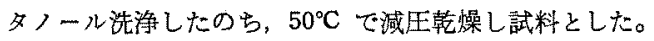

スチレンは南販をママーを $10 \%$ カ性ソーがで 3 回, 水で 3 回洗浄し一夜塩化カルシウムで充分脱水したのb 淢王蒸留して冷蔵㡹中に保存し, 使用のたびに再び減圧 で蒸留して用いた。

メタフールは㯕特級試薬をさらにすら一度蒸留して 実験に用いた。

水は 1 回イオン交換した純水をさらに過マンガン酸カ リアルカリ性で1回, 過マンガン酸カリ酸性で1回, 重 クロム酸カリを加えて1回, さらにも弓 1 回, 計 4 回蒸 留を繰返したるのを用いた。

第一鉄塩は市股特釉の硫酸第一鉄 $\mathrm{FeSO}_{4} \cdot 7 \mathrm{H}_{2} \mathrm{O}$ をと のま文用いた。

2.2 照 射 